\title{
DESENSITIZING BIOACTIVE AGENTS IMPROVES BOND STRENGTH OF INDIRECT RESIN-CEMENTED RESTORATIONS: PRELIMINARY RESULTS
}

\author{
Fernanda de Carvalho Panzeri PIRES-DE-SOUZA ${ }^{1}$, Fabíola Fiorezi de MARCO ${ }^{2}$, Luciana Assirati CASEMIRO ${ }^{3}$, Heitor PANZERI $^{4}$
}

\author{
1- DDS, MSc, PhD Associate Professor, Department of Dental Materials and Prosthodontics, School of Dentistry of Ribeirão Preto, University \\ of São Paulo, Ribeirão Preto, SP, Brazil. \\ 2- DDS Undergraduate student, School of Dentistry of Ribeirão Preto, University of São Paulo, Ribeirão Preto, SP, Brazil. \\ 3- DDS, MSc, PhD Professor, Dentistry Course, University of Franca, Franca, SP, Brazil. \\ 4- DDS, MSc, PhD Full Professor, Department of Dental Materials and Prosthodontics, School of Dentistry of Ribeirão Preto, University of São \\ Paulo, Ribeirão Preto, SP, Brazil.
}

Corresponding address: Fernanda de Carvalho Panzeri Pires-de-Souza - Faculdade de Odontologia de Ribeirão Preto - Av. do Café, s/n ${ }^{\circ}$, Monte Alegre, Ribeirão Preto, SP, Brasil - 14040-904 - Phone: 551636024152 - Fax: 551639173384 - e-mail: ferpanzeri@forp.usp.br

Received: September 11, 2006 - Modification: November 23, 2006 - Accepted: March 02, 2007

\begin{abstract}
$O$

bjective: The aim of this study was to assess the bond strength of indirect composite restorations cemented with a resinbased cement associated with etch-and-rinse and self-etching primer adhesive systems to dentin treated or not with a bioactive material. Materials and Method: Twenty bovine incisor crowns had the buccal enamel removed and the dentin ground flat. The teeth were assigned to 4 groups $(\mathrm{n}=5)$ : Group I: acid etching + Prime \& Bond NT (Dentsply); Group II: application of a bioactive glass $\left(\right.$ Biosilicato $\left.^{\circledR}\right)+$ acid etching + Prime \& Bond NT; Group III: One-up Bond F (J Morita); Group IV: Biosilicato ${ }^{\circledR}+$ One-up Bond F. Indirect composite resin (Artglass, Kulzer) cylinders $(6 \times 10 \mathrm{~mm})$ were fabricated and cemented to the teeth with a dualcure resin-based cement (Enforce, Dentsply). After cementation, the specimens were stored in artificial saliva at $37^{\circ} \mathrm{C}$ for 30 days and thereafter tested in tensile strength in a universal testing machine (EMIC) with $50 \mathrm{kgf}$ load cell at a crosshead speed of $1 \mathrm{~mm} / \mathrm{min}$. Failure modes were assessed under scanning electron microscopy. Data were analyzed statistically by ANOVA and Tukey's test ( $95 \%$ level of confidence). Results: Groups I, II and III had statistically similar results (p $>0.05)$. Group IV had statistically significant higher bond strength means $(p<0.05)$ than the other groups. The analysis of the debonded surfaces showed a predominance of adhesive failure mode for Group III and mixed failure mode for the other groups. Conclusion: The use of desensitizing agent did not affect negatively the bonding of the indirect composite restorations to dentin, independently of the tested adhesive systems.
\end{abstract}

Uniterms: Adhesive system; Etch-and-rinse adhesive systems; Self-etching primer adhesive systems; Dentin desensitizer; Bioactive glass.

\section{INTRODUCTION}

There is a chance of indirect pulpal injury during restorative procedures ${ }^{47}$. In cavities prepared to receive restorative materials, factors such as margin location, cavity depth and remaining sound tooth structure are important for a good prognosis. To avoid thermomechanical shortcomings, it has been recommended to seal dentinal tubules soon after tooth preparation ${ }^{30}$ with varnishes, bactericidal solutions, silver and/or potassium nitrate ${ }^{34}$. In addition, dentin adhesives represent a more contemporary approach $^{23,38}$. However, understanding the interactions between contemporary adhesive strategies (etch-and-rinse, self-etching, one-step protocols) $)^{14}$ and sealing agents is a key factor to improve bond durability $17,25,30,35,40,47,58$.
Dentin hypersensitivity is characterized by a short, sharp pain arising from exposed dentin in response to tactile, evaporative, chemical or thermal stimuli and which cannot be ascribed to any other dental defect or pathology ${ }^{5,34}$. The prevalence of dentinal hypersensitivity has been reported over the years in a variety of ways: greater than 40 million people in the U.S. annually ${ }^{26}, 14.3 \%$ of all dental patients ${ }^{16}$, between $8 \%$ and $57 \%$ of adult dentate population ${ }^{24}$, and up to $30 \%$ of adults at some time during their lifetime ${ }^{1}$.

One of the proposed treatments for dentin hypersensitivity is the use of potassium oxalate-based desensitizing agents on etched dentin before placing the adhesive $^{36,50}$. The lack of calcium ions on dentin surface, due to demineralization after acid etching, allows oxalate ions to spread within dentinal tubules in order to bind to 
calcium ions in the demineralized area. The oxalate crystal obliterates the dentinal tubules and reduces the hydraulic movement ${ }^{36}$.

Efforts on adequate tubule occlusion have led to the development of bioactive glasses. Developed in 1969 by Larry Hench, who defined this type of product as "a bioactive material that produces a specific biological response on the interface that results on the formation of a bonding between tissue and material" 39 , the bioactive glasses have the capacity of chemically bonding to bone and dental tissue through the formation of a carbonate hydroxyapatite layer that presents structure and chemical composition identical to that of the mineral phase of the bone and dental tissue ${ }^{20}$.

The mechanism of action of bioactive glasses is based both on occlusion of dentinal tubules by particles with diameters close to that of the tubules and on desensitization by interruption of neural activation and painful stimuli ${ }^{22}$. Bioactive glasses are able to eliminate dentinal sensitivity for a much longer period than that offered by current treatments ${ }^{39,41}$. In addition, the particles previously bonded to the dental tissue undergo dissolution within the oral environment and constantly release calcium and phosphate ions (two components of bioactive glass) to the oral environment, which elevates the local $\mathrm{pH}$ and favors the process of tooth remineralization ${ }^{37,41}$.

In Brazil, a crystalline bioglass for dentin desensitization (called Biosilicato ${ }^{\circledR}$ ) has been recently developed and patented $^{41,60}$. This material is very similar to Bioglass 45S5, which contains, among other components, $\mathrm{Na}_{2} \mathrm{O}, \mathrm{CaO}, \mathrm{SiO}_{2}$ and $\mathrm{P}_{2} \mathrm{O}_{5}$. It is currently under investigation in dental research.

The aim of this study was to assess the bond strength of indirect composite restorations cemented with a resinbased cement associated with etch-and-rinse and selfetching primer adhesive systems to dentin treated or not with a bioactive material. The null hypothesis was that the use of a bioactive material as a desensitizing agent would decrease the bond strength of indirect resin-cemented restorations

\section{MATERIALAND METHODS}

The materials used in this study are presented in Table 1. Twenty bovine incisors had had their roots removed and the crowns were embedded with autopolymerizing acrylic resin in PVC rings with their surface parallel to the horizontal plane. Next, the enamel of the buccal surface was removed and the dentin was wet-ground flat with 400 and 800-grit $\mathrm{SiC}$ papers and stored in the refrigerator. The specimens were rinsed for 1 minute with deionized water.

The teeth were assigned to 4 groups $(n=5)$ with different treatment protocols, as show on Table 1. Groups II and IV were treated with Biosilicato ${ }^{\circledR}(0.5 \mathrm{~g} /$ teeth $)$, which was applied/ rubbed on the dentin surface for 10 seconds after mixing the powder to distilled water at a ratio of $3: 1$.

Twenty 6-mm-diameter composite resin (Artglass, Heraus
Kulzer, Germany, lot\#010113) cylinders were obtained using a split 10-mm brass matrix (Figure 1). The resin was inserted in increments into the matrix with the aid of a stainless steel spatula and light cured in 180-second cycles in a UniXS unit (Hareaus Kulzer, Germany). Before placing the last increment, a $0.7-\mathrm{mm}$ orthodontic wire loop was added to each specimen.

The composite resin cylinders were cemented to dentin with a dual-cure resin-based cement (Enforce, Dentsply, Petropólis, RJ, Brazil). For this, equal amounts of base and catalyzing pastes were mixed for 20 seconds and the material was applied to dentin and to the composite surface. The composite resin cylinder was positioned under gradual pressure. Excess material was removed using an explorer and the material was light cured for 20 seconds (Ultralux; Dabi Atlante, Ribeirão Preto, SP, Brazil).

All specimens were stored for 30 days in artificial saliva at $37^{\circ} \mathrm{C}$, despite knowing the effect of humidity in the degrading process of adhesive systems ${ }^{8,9,11}$. After this period, the specimens were removed from saliva and, $24 \mathrm{~h}$ later ${ }^{11}$, tensile bond strength was tested in a universal testing machine (EMIC, São José dos Pinhais, PR, Brazil) (Figure 2) at a crosshead speed of $1 \mathrm{~mm} / \mathrm{min}$ and the highest value of load required to dislodge each specimen was divided by the bonding area $\left(0.2826 \mathrm{~cm}^{2}\right)$.

After debonding, the specimens were mounted on aluminum stubs, sputter-coated with gold and the fractured surfaces were analyzed with a scanning electronic microscope (JEOL JSM7500, Tokyo, Japan) at 150X to 2000X magnification to assess the failure mode (adhesive, cohesive or mixed). Kolmogorov-Smirnov test determined a normal data distribution and 2-way ANOVA (adhesive, bioactive glass) was performed to assess significant differences among groups at 5\% significance level.

\section{RESULTS}

Statistical analysis showed that there was no significant interaction between adhesive and bioactive material $(p>0.05)$. No statistically significant differences $(p>0.05)$ were observed between the etch-and-rinse (Group I) and the selfetching (Group III) adhesive systems without surface treatment. No statistically significant differences $(\mathrm{p}>0.05)$ were found between Groups I (one-step) and II (one-step after application of bioglass). However, statistically significant differences $(p<0.001)$ were found between groups III (self-etching) and IV (self-etching after application of bioglass) (Table 2).

Cohesive, adhesive and mixed failures were observed in the four groups. In Groups I and III there was a predominance of mixed fractures. In group III most fractures were adhesive, while in group IV, mixed and cohesive failures were present in a similar number (Figures 3 to 6 ). 
TABLE 1- Materials used and treatment protocol

\begin{tabular}{|c|c|c|c|c|}
\hline Commercial Brand & Composition & & Treatment protocol & Manufacturer \\
\hline $\begin{array}{l}\text { Prime \& Bond NT } \\
\text { ( E t c h-a n d - r in s e } \\
\text { nanofilled adhesive } \\
\text { system) }\end{array}$ & $\begin{array}{l}\text { PENTA, UDMA, acetone, } \\
\text { nanofiller, cetylamine } \\
\text { hydrofluoride, initiators, } \\
\text { stabilizers (Lot \# } 32.010 \text { ) }\end{array}$ & $\begin{array}{l}\text { Group I }(n=5) \\
\text { Group II }(n=5)\end{array}$ & $\begin{array}{l}37 \% \text { phosphoric acid etching for } \\
10 \mathrm{~s} \text {, rinsing, gentle air drying, } \\
\text { application of } 2 \text { layers of the } \\
\text { adhesive system, light curing for } \\
20 \mathrm{~s} \\
\text { Application of bioglass, drying, } \\
37 \% \text { phosphoric acid etching for } \\
10 \mathrm{~s} \text {, rinsing, gentle air drying, } \\
\text { application of } 2 \text { layers of the } \\
\text { adhesive system, light curing for } \\
20 \mathrm{~s}\end{array}$ & $\begin{array}{l}\text { Dentsply, Rio de } \\
\text { Janeiro, Brazil }\end{array}$ \\
\hline
\end{tabular}

One-up bond $\mathrm{F}$

(Fluoride-releasing selfetching primer adhesive system)
Water, MMA, HEMA, coumarin

dye,

methacryloyloxyalkyl acid phosphate,

MAC-10, multifunctional methacrylic

monomer, FASG, photoinitiator (aryl borate catalyst) (Lot \# U4830Z1)
Group III (n=5)

Application of 2 layers of the adhesive system, light curing for $20 \mathrm{~s}$

Group IV ( $n=5) \quad$ Application of bioglass, drying, application of 2 layers of the adhesive system, light curing for $20 \mathrm{~s}$
J Morita, Osaka, Japan
Enforce

(Dual cure resin-based cement)
Base paste: TEGDMA, boron glass, aluminum silicate and silanized barium, silanized pyrolytic silica camphoroquinone, EDAB, BHT, mineral pigments, DHEPT Catalyzing paste: titanium dioxide, silanized pyrolytic silica, mineral pigment, BisGMA, BHT, EDAB, TEGDMA, benzoyl peroxide

\begin{tabular}{|c|c|c|}
\hline $\begin{array}{l}\text { Artglass } \\
\text { (Indirect } \\
\text { resin) }\end{array}$ & composite & $\begin{array}{l}\text { Multifunctional methacrylic } \\
\text { ester, barium alumina, silica } \\
\text { glass }\end{array}$ \\
\hline
\end{tabular}

Application and light curing for $40 \mathrm{~s}$
Dentsply, Rio de Janeiro, Brasil

PENTA: dipentaerythritol penta acrylate monophosphate; UDMA, urethane dimethacrylate; MMA, methyl methacrylate; HEMA, 2-hydroxylethyl methacrylate; MAC-10, methacryloxyundecane dicarboxylic acid; FASG: fluoroaluminosilicate glass; TEGDMA: Triethylene glycol dimethacrylate; EDAB: ethyl-4-dimethylaminobenzoate; BHT: 2,6-di-tert-butyl-p-cresol; DHEPT: N,N,dihydroxyethyl-p-toluidine; Bis-GMA, bisphenol A diglycidyl ether dimethacrylate

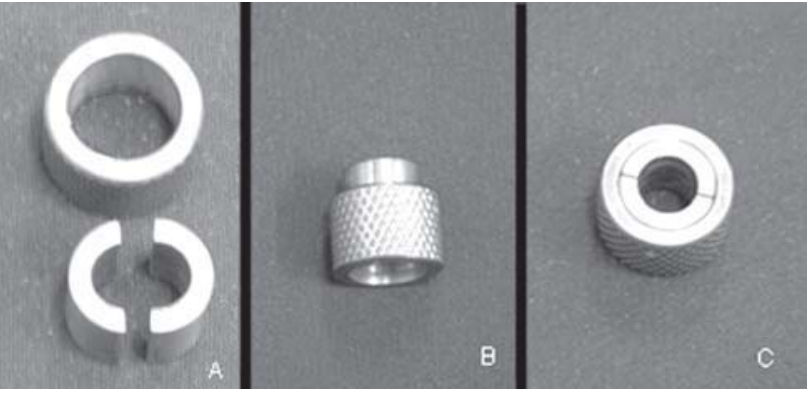

FIGURE 1- Matrix used for fabrication of the composite resin specimens. A) disassembled; B) attached; and C) assembled

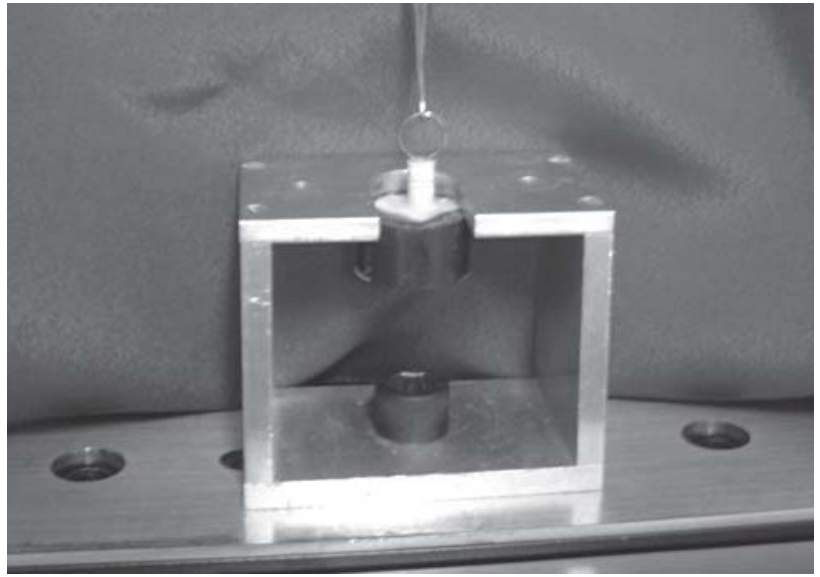

FIGURE 2- Specimens subjected to bond strength (loop) testing in a universal testing machine 


\section{DISCUSSION}

The methodology used in this study is similar to that found in the literature ${ }^{13,31,42}$. Yet, other authors have advocated the use of microtensile bond strength tests ${ }^{6,10,21,49}$. Bond strength tests are the most frequently used to screen adhesives ${ }^{14}$. Despite the fact that bond strength results are inconclusive regarding the properties of adhesive systems, they may, however, be valuable for comparing different materials ${ }^{14}$. The loop test was chosen for this study because

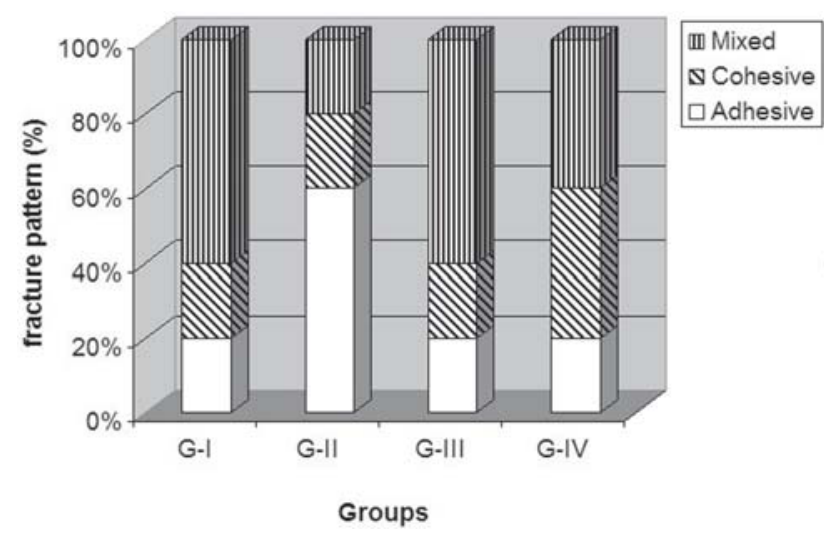

FIGURE 3- Failure modes (\%) for the studied groups

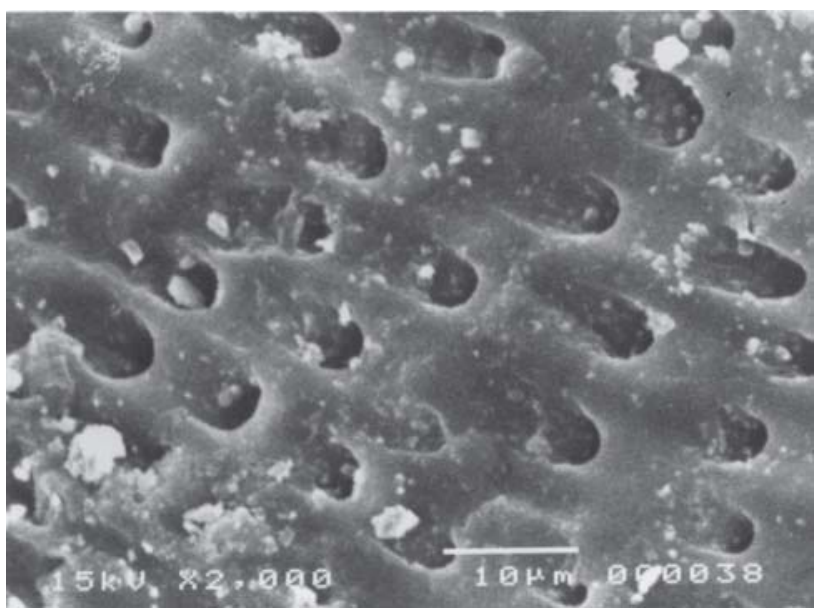

FIGURE 4- SEM micrograph of adhesive failure (G-IV 2000x) indirect composite resin restoration cemented on dentin tends to become a single body, which has the capacity of withstanding or dispersing the tensions suffered on all its extension ${ }^{31}$. In addition, it would make the debonded surface more appropriate for SEM analysis, thus allowing identifying the most common fracture patterns according to the type of dentin adhesive used ${ }^{42}$. The substrate used in this study was bovine dentin, similar to that of other studies ${ }^{6,12,13,31,32,48}$. No significant differences being observed between bovine and human dentin ${ }^{43}$.

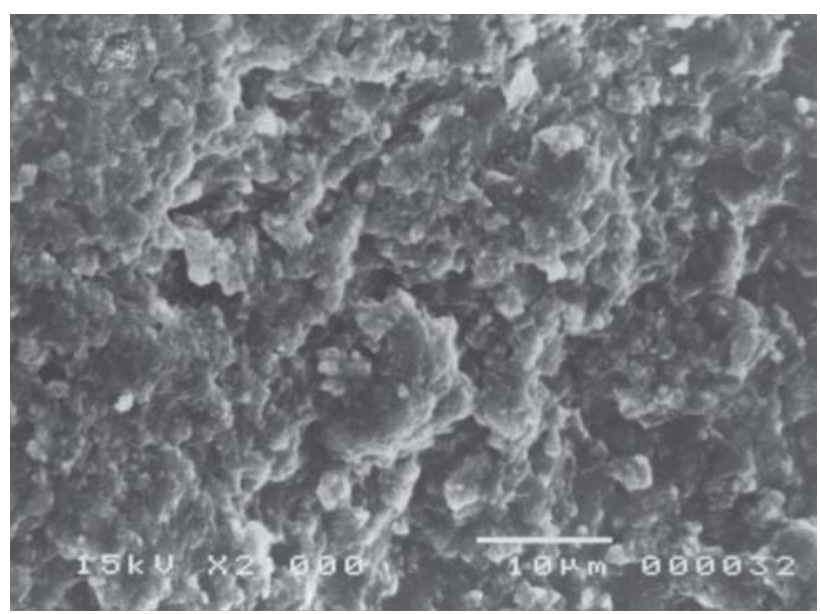

FIGURE 5- SEM micrograph of cohesive failure (G-IV 2000x)

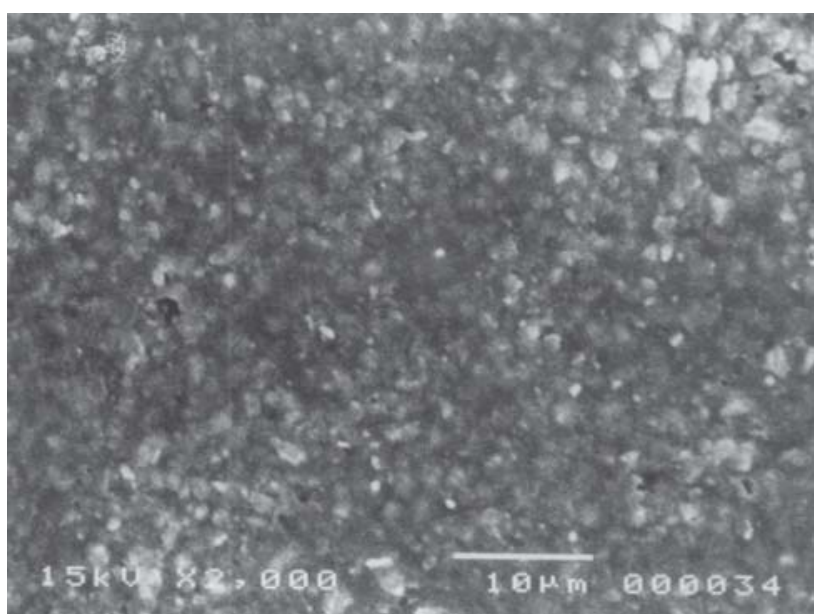

FIGURE 6- SEM micrograph of mixed failure (G-IV - 2000x)

TABLE 2- Bond strength means (MPa) with and without application of bioactive glass

G-I

(Etch-and-rinse adhesive system)
G-II

(Etch-and-rinse adhesive system + Bioglass)

\section{G-III}

(Self-etching adhesive system)

\section{G-IV}

(Self-etching adhesive system + Bioglass) 
Currently, the most appropriate method for in vitro bond strength testing, which provides closer values to those of the clinical condition (in vivo), must involve aging of specimens bonded to substrate ${ }^{14}$. Most studies report a significant decrease in bond strengths, even after relatively short storage periods caused by degradation of interface components by hydrolysis (mainly resin and/or collagen $)^{3,4,15,19}$. Nevertheless, water can also infiltrate and affect negatively the mechanical properties of the polymer matrix, by swelling and reducing the frictional forces between the polymer chains, a process known as 'plasticization' 28,45 . Artificial saliva solutions can also be used, but the decrease of bond strength has been shown to be similar to that obtained with pure water degradation ${ }^{27}$. Thus, the present study assessed the bond strength of indirect restorations with longer clinical cementation time, which had previously suffered degradation to its adhesive interface.

The quality of bonding of restorative material to tooth substrate depends on several factors, such as the adhesive system, handling characteristics and the substrate itself. Applying desensitizing products on dentin may promote alterations to its structure and influence the adhesion process $^{59}$. In the present study, the desensitizing agent evaluated was Biosilicato ${ }^{\circledR 37,41,60}$, a recently developed bioglass that has shown excellent clinical results in in vitro tests $^{29,53}$. Prime \& Bond NT (etch-and-prime) and One-up Bond F (self-etching primer) were the adhesive systems of choice. It has been suggested that they are less technique sensitivity and improve clinical efficiency by reducing chairside time ${ }^{54}$. However, this may make bonding more susceptible to the effects of post-polymerization water, which may compromise the bonding quality ${ }^{18}$. After performing the loop tests in Groups I and III, it was observed that there were no statistically significant differences between the bond strengths of the etch-and-rinse and the self-etching primer adhesive systems. These results confirm those previously reported by Giannini, et al. ${ }^{19}$ (2003), who compared materials with the same characteristics and found similar results.

It is known that the efficiency of a dentin adhesive depends, among other factors, on the organic solvent in its composition $^{28}$. According to Tay, et al. ${ }^{51}$ (2002), self-etching primer adhesive systems are permeable membranes, and the action of water on the cured adhesive layer is associated with its hydrophilicity. Water is easily absorbed and accumulates in areas with internal porosity and where hydrophilic molecules are located ${ }^{52}$. The present study used adhesive systems with two different solvents. Prime Bond NT uses acetone in its composition, while One-Up Bond has alcohol/water as solvent. Hence, it was expected that the acetone-based material would have higher bond strengths compared to alcohol/water-based system because it is more hydrophilic. Moreover, lower bond strength was expected due to incomplete monomer polymerization ${ }^{57}$. In addition, most of the currently available self-etching primer adhesives are methacrylate-based with a $\mathrm{pH}$-value from 1.52.5. Under these strong acidic conditions, esters such as 2hydroxyethyl methacrylate (HEMA), triethyleneglycol dimethacrylate (TEGDMA), methacryloyloxydecyl dihydrogen phosphate (MDP) or HEMA-phosphate, are hydrolytically degraded ${ }^{33,44}$. However, acetone-based adhesives are more sensitive to the adhesive technique $e^{55,56}$, which is a possible explanation for the lower bond strength.

Comparing the groups in which the etch-and-rinse adhesive system was used, Group I (adhesive) had higher bond strength means than Group II (adhesive after application of Biosilicato $\left.{ }^{\circledR}\right)$. However, there were no statistically significant differences between them $(p>0.05)$. For this type of adhesive, which requires previous acid etching, the obliteration of the dentinal tubules with Biosilicato (Group II) did not reduce bond strength. This is a favorable condition because the use of a desensitizing agent prior to cementation of indirect restorations may reduce postoperative sensitivity ${ }^{30}$ and improve clinical success. The fact that bioglass has $\mathrm{P}_{2} \mathrm{O}_{5}$ in its composition may result in stronger affinity with calcium in dentin. This is due to the fact that, as observed with organic phosphates added to dentifrices, these components act as calcium sequestrants ${ }^{7}$, forming compounds that accumulate in the internal portion of the dentinal tubule. However, it does not preclude bonding stability. The results of the present study disagree with those of a recent study ${ }^{59}$, which indicated that the carbonate hydroxyapatite crystal has higher stability than calcium oxalate for Prime Bond NT.

Comparing the groups in which the self-etching primer adhesive system was used, Group IV (adhesive after application of Biosilicato ${ }^{\circledR}$ ) had statistically significant higher bond strength means than Group III (adhesive) $(p<0.001)$. The use of the desensitizing agent (Group IV) enhanced the adhesion, with a possible favorable interaction between the carbonate hydroxyapatite layer, formed after applying Biosilicato $^{20,39}$ and the respective adhesive system. A possible explanation for this would be the presence of methacrylate phosphates, which are used in self-etching adhesive systems to make them more hydrolytically stable ${ }^{28}$. Thus, the 30-day aging did not interfere with the self-etching adhesive system in the same way as it did with the etchand-rinse adhesive. Differences in concentration of fluoride, $\mathrm{pH}$ values and availability of calcium ions on dentin surface ${ }^{2}$ also contributed for this variation.

These outcomes show that treating the substrate with bioactive glass improved the bonding of the tested materials. Differently from what was expected, the tested bioglass did not narrow or occlude the dentinal tubules, which would hinder the penetration of the adhesive systems. A possible reason for this could be the small size of the bioglass particles ( 0.5 ìm on average). In addition, since the material was mixed with distilled water, it is possible that it did not effectively penetrate the tubulii, which may have led to false results (Figure 3).

Another factor that diverges from which was reported in previous studies refers to the cement used for restoration retention. According to Suh, et al. ${ }^{46}$ (2003), there is an incompatibility between single-step, self-etching adhesive and chemically cured or dual-cured composites due to decoupling of the tertiary amine used in chemically cured 
resins. Nonetheless, we agree with Yiu, et al. ${ }^{59}$ (2005), who stated that effective bonding to the desensitizer-treated acidetched dentin is adhesive-specific, an additional reason that reinforces the hypothesis that material penetration was not effective.

SEM results after applying bioglass (Groups II and IV) showed that dentin surface was characterized by the presence of small granules with irregular shapes randomly spread on dentinal tubules (Figure 4). An interaction was observed between dentin and resin material (mixed failure) despite being evident that some tubules remained without material (Figure 6). The knowledge of this structure is of foremost, importance, especially its interaction with the adhesive systems, due to the previously addressed reasons. Further studies should be performed to better understand this structure and its possible interactions with restorative materials

\section{CONCLUSION}

Based on the outcomes of the present study, it may be concluded that the bioactive glass produced higher bond strength for the self-etching primer adhesive. The use of adesensitizing agent did not affect negatively the bonding of the indirect composite restorations to dentin, independently of the tested adhesive systems.

\section{REFERENCES}

1- Addy M. Etiology and clinical implications of dentine hypersensitivity. Dent Clin North Am. 1990;34:503-14.

2-Arends J, Reintsema H, Dijkman TG. 'Calcium fluoride-like' material formed in partially demineralized human enamel in vivo owing to the action of fluoridated toothpastes. Acta Odontol Scand. 1988;46:347-53.

3- Armstrong SR, Keller JC, Boyer DB. The influence of water storage and $\mathrm{C}$-factor on the dentin-resin composite microtensile bond strength and debond pathway utilizing a filled and unfilled adhesive resin. Dent Mater. 2001;17:268-76.

4- Armstrong SR, Vargas MA, Fang Q, Laffoon JE. Microtensile bond strength of a total-etch 3-step, total-etch 2-step, self-etch 2-step, and a self-etch 1-step dentin bonding system through 15-month water storage. J Adhes Dent. 2003;5:47-56.

5- Assis CD, Antoniazzi RP, Zanatta FB, Rosing CK. Efficacy of Gluma Desensitizer(R) on dentin hypersensitivity in periodontally treated patients. Pesqui Odontol Bras. 2006;20:252-6.

6- Bouillaguet S, Gysi P, Wataha JC, Ciucchi B, Cattani M, Godin C, et al. Bond strength of composite to dentin using conventional, onestep, and self-etching adhesive systems. J Dent. 2001;29:55-61.

7- Brazel CS, Peppas NA. Mechanisms of solute and drug transport in relaxing, swellable hyrophilic glassy polymers. Polymer. 1999;40:3383-98

8- Carrilho MR, Carvalho RM, Tay FR, Pashley DH. Effects of storage media on mechanical properties of adhesive systems. Am J Dent. 2004; $17: 104-8$
9- Carrilho MR, Carvalho RM, Tay FR, Yiu C, Pashley DH. Durability of resin-dentin bonds related to water and oil storage. Am J Dent. 2005;18:315-9.

10- Carrilho MR, Reis A, Loguercio AD, Rodrigues LE Filho. Bond strength of four adhesive systems to dentin. Pesqui Odontol Bras. 2002;16:251-6.

11- Carvalho RM, Tay FR, Giannini M, Pashley DH. Effects of preand post-bonding hydration on bond strength to dentin. J Adhes Dent. 2004;6:13-7.

12- Chaves E. Influência do tempo de armazenagem inicial na resistência à tração de cimentos resinosos unidos à dentina [tese]. Piracicaba (SP): Universidade de Campinas; 2002.

13- Cunha MRB. Resistência de união à tração de sistemas adesivos sobre dentina aos 10 minutos e 24 horas pós-polimerização [dissertação]. Piracicaba (SP): Universidade de Campinas; 2001.

14- De Munck J, Van Landuyt K, Peumans M, Poitevin A, Lambrechts $\mathrm{P}$, Braem M, et al. A critical review of the durability of adhesion to tooth tissue: methods and results. J Dent Res. 2005;84:118-32.

15- De Munck J, Van Meerbeek B, Yoshida Y, Inoue S, Vargas M, Suzuki K, et al. Four-year water degradation of total-etch adhesives bonded to dentin. J Dent Res. 2003;82:136-40.

16- Dowell P, Addy M. Dentine hypersensitivity: a review. Aetiology, symptoms and theories of pain production. J Clin Periodontol. $1983 ; 10: 341-50$.

17- Felton DA, Bergenholtz G, Kanoy BE. Evaluation of the desensitizing effect of Gluma Dentin Bond on teeth prepared for complete-coverage restorations. Int J Prosthodont. 1991;4:292-8.

18- Garcia F, Wang L, Pereira L, Tay F, Pashley H, Carvalho R. O paradoxo da evolução dos sistemas adesivos. Rev Assoc Paul Cir Dent. 2003;57:449-53.

19- Giannini M, Seixas CA, Reis AF, Pimenta LA. Six-month storagetime evaluation of one-bottle adhesive systems to dentin. J Esthet Restor Dent. 2003;15:43-8; discussion 49.

20- Gillam DG, Tang JY, Mordan NJ, Newman HN. The effects of a novel Bioglass dentifrice on dentine sensitivity: a scanning electron microscopy investigation. J Oral Rehabil. 2002;29:305-13.

21- Hashimoto M, Ohno H, Yoshida E, Hori M, Sano H, Kaga M, et al. Resin-enamel bonds made with self-etching primers on ground enamel. Eur J Oral Sci. 2003;111:447-53.

22- Hilgert LA, Silva SBA, Masotti AS, Coceição EN. Resistência de união à dentina de um sistema adesivo convencional após aplicação de dessensibilizantes dentinários. JBC J Bras Clin Odontol Integr. 2004;43:21-4.

23- Ianzano JA, Gwinnett AJ, Westbay G. Polymeric sealing of dentinal tubules to control sensitivity: preliminary observations. Periodontal Clin Investig. 1993;15:13-6.

24- Irwin CR, McCusker P. Prevalence of dentine hypersensitivity in a general dental population. J Ir Dent Assoc. 1997;43:7-9.

25- Johnson GH, Hazelton LR, Bales DJ, Lepe X. The effect of a resin-based sealer on crown retention for three types of cement. J Prosthet Dent. 2004;91:428-35.

26- Kanapka JA. Current treatment for dentinal hypersensitivity: a new agent. Compend Contin Educ Dent. 1982;Suppl 3:S118-20. 
27- Kitasako Y, Burrow MF, Nikaido T, Tagami J. The influence of storage solution on dentin bond durability of resin cement. Dent Mater. 2000;16:1-6.

28- Malacarne J, Carvalho RM, Goes MF, Svizero N, Pashley DH, Tay FR, et al. Water sorption/solubility of dental adhesive resins. Dent Mater. 2006;22:973-80

29- Martins CHG, Casemiro LA, Carvalho TC, Souza FR, Vinholis AHC, Pires-de-Souza FCP, et al. Avaliação da atividade antimicrobiana in vitro de um novo biovidro frente a microrganismos da cavidade bucal [resumo Ib075]. Braz Oral Res. 2006;20 Suppl:167. Apresentado na $23^{\text {a }}$ Reunião Anual da Sociedade Brasileira de Pesquisa Odontológica; 2006 set 4-6; Atibaia, SP.

30- Mausner IK, Goldstein GR, Georgescu M. Effect of two dentinal desensitizing agents on retention of complete cast coping using four cements. J Prosthet Dent. 1996;75:129-34.

31- Mota CS, Demarco FF, Camacho GB, Powers JM. Tensile bond strength of four resin luting agents bonded to bovine enamel and dentin. J Prosthet Dent. 2003;89:558-64.

32- Nakamichi I, Iwaku M, Fusayama T. Bovine teeth as possible substitutes in the adhesion test. J Dent Res. 1983:62:1076-81.

33- Nishiyama N, Suzuki K, Yoshida H, Teshima H, Nemoto K. Hydrolytic stability of methacrylamide in acidic aqueous solution. Biomaterials. 2004;25:965-9.

34- Orchardson R, Collins WJ. Clinical features of hypersensitive teeth. Br Dent J. 1987;162:253-6.

35- Pameijer CH, Hulten J, Glantz PO, Randow K. Influence of lowviscosity liners on the retention of three luting materials. Int $\mathrm{J}$ Periodontics Restorative Dent. 1992;12:195-205.

36- Pashley DH, Carvalho RM, Pereira JC, Villanueva R, Tay FR. The use of oxalate to reduce dentin permeability under adhesive restorations. Am J Dent. 2001;14:89-94.

37- Pashley DH, Carvalho RM. Dentine permeability and dentine adhesion. J Dent. 1997;25:355-72.

38- Pashley EL, Comer RW, Simpson MD, Horner JA, Pashley DH Caughman WF. Dentin permeability: sealing the dentin in crown preparations. Oper Dent. 1992;17:13-20.

39- Peitl-Filho O. Vitro-cerâmica Bioativa de Alto Desempenho Mecânico [tese]. São Carlos (SP): Universidade Federal de São Carlos 1995.

40- Quarnstrom F, Collier N, McDade E, McLean K, Munk A, Nicholls J. A randomized clinical trial of agents to reduce sensitivity after crown cementation. Gen Dent. 1998;46:68-74.

41- Ravagnani C. Biosilicato para promoção da saúde oral. São Carlos: Universidade Federal de São Carlos; 2003.

42- Ribeiro LL, Sá FC, Franco EB, Navarro MFL. Evaluation of the interaction between composite resin and different dentin adhesives. Rev Odontol Univ São Paulo. 1999;13:31-6.

43- Saleh F, Taymour N. Validity of using bovine teeth as a substitute for human counterparts in adhesive tests. East Mediterr Health J. $2003 ; 9: 201-7$

44- Salz U, Zimmermann J, Zeuner F, Moszner N. Hydrolytic stability of self-etching adhesive systems. J Adhes Dent. 2005;7:107-16.
45- Santerre JP, Shajii L, Leung BW. Relation of dental composite formulations to their degradation and the release of hydrolyzed polymeric-resin-derived products. Crit Rev Oral Biol Med. $2001 ; 12: 136-51$

46- Suh BI, Feng L, Pashley DH, Tay FR. Factors contributing to the incompatibility between simplified-step adhesives and chemicallycured or dual-cured composites. Part III. Effect of acidic resin monomers. J Adhes Dent. 2003;5:267-82.

47- Swift EJ Jr, Lloyd AH, Felton DA. The effect of resin desensitizing agents on crown retention. J Am Dent Assoc. 1997;128:195-200.

48- Swift EJ Jr, Perdigao J, Combe EC, Simpson CH 3rd, Nunes MF. Effects of restorative and adhesive curing methods on dentin bond strengths. Am J Dent. 2001;14:137-40.

49- Takahashi A, Sato Y, Uno S, Pereira PN, Sano H. Effects of mechanical properties of adhesive resins on bond strength to dentin. Dent Mater. 2002;18:263-8

50- Tay FR, Pashley DH, Mak YF, Carvalho RM, Lai SC, Suh BI. Integrating oxalate desensitizers with total-etch two-step adhesive. J Dent Res. 2003;82:703-7.

51- Tay FR, Pashley DH, Suh BI, Carvalho RM, Itthagarun A. Singlestep adhesives are permeable membranes. J Dent. 2002;30:371-82.

52- Tay FR, Pashley DH. Water treeing - a potential mechanism for degradation of dentin adhesives. Am J Dent. 2003;16:6-12.

53- Tirapelli C, Ravagnani C, Peitl-Filho O, Zanotto ED, Panzeri H. Efeito de um material bioativo na oclusão de túbulos dentinários: investigação em microscopia eletrônica de varredura [resumo Pa242]. Braz Oral Res. 2006;20 Suppl:181. Apresentado na 23 ${ }^{\mathrm{a}}$ Reunião Anual da Sociedade Brasileira de Pesquisa Odontológica; 2006 set 4-6; Atibaia, SP.

54- Van Landuyt KL, Kanumilli P, De Munck J, Peumans M, Lambrechts P, Van Meerbeek B. Bond strength of a mild self-etch adhesive with and without prior acid-etching. J Dent. 2006;34:7785 .

55- Van-Meerbeek B, De-Munck J, Yoshida Y, Inoue S, Vargas M, Vijay P, et al. Buonocore memorial lecture: adhesion to enamel and dentin: current status and future challenges. Oper Dent. 2003;28:21535 .

56- Van-Meerbeek B, Vargas M, Inoue S, Yoshida Y, Peumans M, Lambrechts $\mathrm{P}$, et al. Adhesives and cements to promote preservation dentistry. Oper Dent. 2001;26:S119-S44.

57- Yesilyurt C, Bulucu B. Bond strength of total-etch and self-etch dentin adhesive systems on peripheral and central dentinal tissue: a microtensile bond strength test. J Contemp Dent Pract. 2006;7:2636 .

58- Yim NH, Rueggeberg FA, Caughman WF, Gardner FM, Pashley DH. Effect of dentin desensitizers and cementing agents on retention of full crowns using standardized crown preparations. J Prosthet Dent. $2000 ; 83: 459-65$

59- Yiu CK, King NM, Suh BI, Sharp LJ, Carvalho RM, Pashley DH, et al. Incompatibility of oxalate desensitizers with acidic, fluoridecontaining total-etch adhesives. J Dent Res. 2005;84:730-5.

60- Zanotto ED, Ravagnani C, Peitl P Filho, Panzeri H, Lara EHG, inventores; Fundação Universidade Federal de São Carlos, Universidade de São Paulo, depositantes. Processo de preparação de biosilicatos particulados bioativos e reabsorvíveis, composições para preparar ditos biosilicatos, biosilicatos particulados e reabsorvíveis e uso dos mesmos no tratamento de afecções bucais. BR PI0300644-1. 2003 feb. 20 . 